CHA NGING PLACES 



\title{
Changing Places
}

THE SCIENCE AND ART OF NEW URBAN PLANNING

\author{
JOHN MACDONALD
}

\author{
CHARLES BRANAS
}

ROBERT STOKES

PRINCETON UNIVERSITY PRESS

PRINCETON \& OXFORD 
Copyright (C) 2019 by Princeton University Press

Published by Princeton University Press

41 William Street, Princeton, New Jersey o8540

6 Oxford Street, Woodstock, Oxfordshire Ox20 1TR

press.princeton.edu

All Rights Reserved

ISBN 978-0-691-19521-6

ISBN (e-book) 978-o-691-19779-1

British Library Cataloging-in-Publication Data is available

Editorial: Meagan Levinson and Jacqueline Delaney

Production Editorial: Kathleen Cioffi

Jacket Design: Layla Mac Rory

Production: Erin Suydam

Publicity: Tayler Lord and Kathryn Stevens

Jacket image (background): Empty lot and homes in the Fishtown

neighborhood of Philadelphia, PA. (C) Frances Roberts / Alamy Stock Photo

This book has been composed in Arno

Printed on acid-free paper. $\infty$

Printed in the United States of America

$\begin{array}{llllllllll}10 & 9 & 8 & 7 & 6 & 5 & 4 & 3 & 2 & 1\end{array}$ 